\title{
Waste Management Coordination in Mebidangro, Indonesia: Perspective of Public Administration
}

\author{
Februati Trimurni' ${ }^{1}$, Dayana² \\ Department of Public Administration ${ }^{1}$ \\ Department of Communication ${ }^{2}$ \\ University of Sumatera Utara, Medan, Indonesia \\ feb_tambunan@yahoo.com,bu_dayana@yahoo.com
}

\begin{abstract}
This study aims to explain coordination system on waste management in the integrated area of Mebidangro, Indonesia. Waste management has been issue in the area and it is mainly linked to the institutional sector handling on waste management. The provincial government as the coordinator for district or municipal governments in the context of integrated area doesn't have sole authority to implement policies on waste management in the region. The existence of autonomous governments at district or municipal level along with their own genuine rights becomes the authority of province on waste management service infinite. It is therefore, the emergence of institution on waste management at provincial level with the involvement of representatives from districts or municipals needed.

The research found the coordination on waste management doesn't properly work in line with the Presidential regulations. The main reasons of this finding are the unavailability of institution to manage waste management issues at provincial level and the waste-related regulations those are needed to synchronize.
\end{abstract}

Keywords: Waste Management, Decentralization, Local Government, Local Institution and Public Administration.

\section{INTRODUCTION}

The area of Medan, Binjai, Deli Serdang and Karo (Mebidangro) in North Sumatra Province has been regulated as integrated area and placed as one of sixty-seven national strategic areas all over the country. The main reason of establishing the area as such is the fact the economic growth of the area has been rapidly increasing in the last three decades and has been placed as main gate of national economy in the western part of the country. Medan as the capital city of the province is also the third largest city in the country where it is surrounded by three districts and urban area of Binjai, Deli Serdang and Karo. On the other hand, the city is also the representation of the country in the regional economic cooperation so called IMT-GT (Indonesia-Malaysia-Thailand Growth Triangle).

The central government of Indonesia has been focusing the infrastructure developments within the area particularly on transportation sector to support the economic development in the area such as the development new airport of Kuala Namu International Airport in Deli Serdang, the construction of highway in the corridor of MedanBinjai-Tebing Tinggi that links the area to important cities and towns within the province, the provision of shuttle bus' in the corridor of Medan-Binjai-Deli Serdang for commuters within the area, building several fly-overs in Medan and the improvement of some national roads in the area and so forth.

The economic, social and population growth in the area of Mebidangro have brought about changes on demographic profile, area topography, environmental quality and consumption pattern of residents. The current issue related on development impacts in the area is the worse of sanitation and drainage system, the piles of waste on some sites of cities or town, the uncontrolled waste volume etc. The lack of waste management system in the area has also generated floods particularly in rainy season all over the city. The consumption pattern and the lack of knowledge and culture on handling domestic waste subsequently contribute the increase of waste volume, waste types and characteristics. The Bureau of National Statistict in 2016 noted the city of Medan generates averagely 1,500 tons of waste per day and the lowest one which is the district of Karo generates about 76 tons of waste in a day. Those number of volume is merely based on the waste number transferred from waste intermediate collection points (TPS) to central dump site/landfills (TPA). 
There are some volumes of waste excluding those number which are directlt burnt by residents, sold to waste recycling agents, recycled by residents or even thrown out to rivers around the area.

Waste management issue is one of problems that most of cities experience. If the waste issue is not part of urban regional plans there must be new problems at least the existence of uncontrollable domestic and non domestic waste piles, air pollution, water and soil pollution as well as environmental destruction. Therefore, it is a must the local government at district and municipal level within the Mebidangro area concern on the waste problem, taking policy and actions to mitigate waste problem, reducing impacts of waste piles and projecting integrated, comprehensive and sustainable waste management frameworks.

This paper aims at analyzing the current waste management coordination system and the pattern of waste management implemented by the provincial government and local governments at district or municipal level in the region. The discussion are stressed on how the provincial government as the coordinator of waste management in the region handling waste issues in the area, how district or municipal government carry out waste management, the possibility of implementing strategic governance potentials on waste management and the potentials of public participation to be attached on government projects on waste management.

\section{MATERIALS AND METHODS}

The study is a qualitative research where indepth interview and observation are main techniques of collecting data. Informants of the research consist of public officials, non-governmental organization, business, media and residents within districts or municipalities in urban area of Mebidangro. The questions during the interview are focussed more on how the provincial government coordinates districts or municipalities on waste management as well as how the districts or municipal government implement waste management in their area. The observation is conducted at some waste intermediate collection points (TPS), waste bin points on public places and some sites of uncontrolled waste piles in settlement areas. Triangulation method is applied in this study to confirm the validity of gained data.

\section{RESULT AND DISCUSSION}

\section{A. Waste Management in the Era of Decentralization}

There are a lot of definitions of waste management proposed by scholars and scientists. Adogu (2015) for instance defines waste management as "the process of collecting, transporting, processing or disposing, managing and monitoring of waste materials". Seadon (2010) states "waste management is viewed as part of a generation, collection and disposal system". According to Law No. $18 / 2008$ on Waste Management states waste management as "a systemic action, comprehensive and sustainable consisting of reducing and handling waste". Above all, waste management is resumed as reducing waste, waste prevention, reuse, material recycling, composting, energy recovery and final disposal.

Nasution (2014) states decentralization concept in Indonesia "is not a new issue; even decentralization has been around since the independence of Indonesia. However, in practice, decentralization does not go well, especially during the New Order Regime, President Suharto". After the political reform of Indonesia in 1998, the government issued Law No. 22/ 1999 on local government which replaced the previous regulation, Law No. 5/1974. Decentralization is defined as the process of political devolution, fiscal and decision-making from central government to local level (Isufaj, 2014).

The law No. 22/ 1999 on local government has been gradually revised respectively the first revision by the Law No.32/2004 and the last through the Law No. 23/2014. The dynamism of the law revision shows at least the country is on the process of improving, adjusting and compromising the better system of local government and the pattern of decentralization and local autonomy in the country. The law No.23/2014 as early mentioned is the newest legal back-up of decentralization and local autonomy in Indonesia. According to the law, waste management is categorized as one public service sectors to be carried out by the district or municipal government. The sector is however categorized as one of eleven affairs on spatial and settlement area of service that means there are authorities of upper level of government which is central and provincial government on the sector. 
The Indonesia Infrastructure Initiative (IndII, 2007) notes Indonesia did not have a certain policy and regulation on waste management by the year of 2007. The regulation on waste management is ultimately issued through the Law No. 18/2008. The background of the regulation itself is based on the fact there were some cases of disaster brought by piles of waste such as that of occurred in West Java etc (Nugraha, 2016). However, the normative reasons of issuing the regulation are at least based on these four points: "(i) the population growth and the changing of public consumption patterns those bring about the increase of waste volume, type and characteristic, (ii) the current waste management is not in line with the technique and method of handling waste, (iii) waste problem has been a national problem that needs to implement comprehensively and integrated from upstream to downstream, and (iv) waste management needs the certain regulation and responsibility of central government, local government as well as the participation of public and business so the waste management is able to work proportionally, effective and efficient" (Law No. $18 / 2008$ on Waste Management).

Waste management in accordance to Law No. $23 / 2014$ is categorized as a concurrent affair where the delivery of services on the sector is divided and shared among central, provincial and district or municipality government. It is then assumed the waste management service is not merely the sole authority of district or municipalities government yet also the central and provincial government have authorities on the sector as described in Table. 1 below. However, by means of local autonomy, district and municipal governments still the party having authority to implement and undertaking waste management in the field.

Table.1. Division of Authorities Among Level of Government on Waste Management

\begin{tabular}{|l|l|}
\hline \multicolumn{1}{|c|}{$\begin{array}{c}\text { Level of } \\
\text { Government }\end{array}$} & \multicolumn{1}{|c|}{ Authority } \\
\hline National & 1. $\begin{array}{l}\text { Regulating policy and national strategy waste } \\
\text { management. }\end{array}$ \\
& 2. $\begin{array}{l}\text { Stating norm, standard, procedures and criteria of } \\
\text { waste management }\end{array}$ \\
3. $\begin{array}{l}\text { Facilitating and Developing Cooperation among } \\
\text { local government, partnership and networks on } \\
\text { waste management. } \\
\text { Applying coordination, guiding and controlling } \\
\text { over local government performance on waste } \\
\text { management } \\
\text { Taking policy on disputes of among and between } \\
\text { local governments on disputes }\end{array}$
\end{tabular}

Table1, cont.

\begin{tabular}{|c|c|}
\hline Province & $\begin{array}{l}\text { 1. Regulating policy and strategy of waste } \\
\text { management in accordance to the national policy. } \\
\text { 2. Facilitating cooperation among or between local } \\
\text { governments in the province, partnership and } \\
\text { networks on waste management } \\
\text { 3. Facilitating settlement of disputes among or } \\
\text { between local governments in the province. }\end{array}$ \\
\hline District/ & $\begin{array}{l}\text { 1. Regulating policy and strategy of waste } \\
\text { management in accordance to the national and } \\
\text { provincial policy. } \\
\text { 2. Conducting waste management in the } \\
\text { district/municipality in line with the norm, } \\
\text { standard, procedures and criteria stated by } \\
\text { national government. } \\
\text { 3. Supervising and controlling of waste management } \\
\text { conducted by other parties. } \\
\text { 4. Stating location for intermediate landfill, } \\
\text { integrated sanitary landfill and ultimate landfill. } \\
\text { Monitoring and Evaluation the sites of ultimate } \\
\text { landfill regularly in each six months for twenty } \\
\text { years. }\end{array}$ \\
\hline
\end{tabular}

Source: Law No. 8/2008 on Waste Management

The logical frame of putting policy on waste management as such is mostly based on the fact that the district or municipal governments are regarded having limitations on carrying out waste management in line with the national policy such as the lack of competency, financial support, human resources and so forth. This situation is more less the same to the opinion of Gortner (1997) that the terms centralization and decentralization refer to the degree to wich decision-making authority is confined to the top echelons of bureau or assigned to the lower echelon offices and officials.

\section{B. Waste Management Coordination System in Mebidangro}

According to the Presidential Regulation No.62/2011, the provincial government of North Sumatera acts as a coordinator in delivering public services in the context of the integrated area of Mebidangro. There are at least seven main sectors to be delivered by provincial and district or municipality level in the area including of land use and development, public services enhancement, quality and access of public services, increasing the quality and quantity of public open space, enhancement the defence and national order, and enhancement the coordination, integration and synchronization the development of the area. The strategy to enhance the quality and access of transportation infrastructure network, energy, telecommunication, water resources and city infrastructure in the area of Mebidangro equally and 
integrated in international, regional and national level.

Kral (2007) states the coordination means into four main definitions which are "the act of coordinating, the regulation of diverse elements into an integrated and harmonious operation, integrating or linking together different parts of an organization [..] and integrating or linking together different resources to accomplish a collective set of tasks." Verhoest on the other hand (Christensen, 2015), classifies coordination into an external-internal and a vertical-horizontal dimension. In line with the above opinion, Hasibuan (2011) states that vertical organizational structure is marked by hierarchy, because of the power context or pattern that flows from top to bottom; while there is horizontal organizational structure when there are more preferences for specialization and participation (Osifo, 2012).

Christensen and Lægreid in Wojtarowicz (2014) distinguish between vertical and horizontal coordination as well as including an internal and external dimension. In the case of waste management in the context of Mebidangro, both types of coordination are applied. An internal-horizontal coordination at the level of provincial government occurs when units of government such as Board of Local Development Planning (Bappeda), Board of Local Environment (Badan Lingkungan Hidup), Board of Spatial and Settlement (Dinas Tarukim) and other Bureaus coordinate works and actions on waste management. An external-horizontal coordination occurs when the province government coordinates with civil society organization or private sector. An internal-vertical coordination of provincial government occurs when the provincial government coordinates works and actions with ministerial or its subordinates on waste management. An externalvertical coordination of provincial government occurs when the provincial government coordinates works and actions with non-governmental parties at the national level on waste management. The type of coordinations is more-less the same to the type of coordination in the district or municipal level. The taxonomy of the mentioned coordination is explained as follows.
Table 2. Taxonomy of Coordination Forms on Waste Management in Mebidangro

\begin{tabular}{|c|c|c|}
\hline \multirow{2}{*}{$\begin{array}{c}\text { Level of } \\
\text { Governmen } \\
t\end{array}$} & \multicolumn{2}{|c|}{ Horizontal Coordination } \\
\hline & Internal & External \\
\hline Provincial & $\begin{array}{l}\text { Coordination } \\
\text { between different } \\
\text { units of provincial } \\
\text { government }\end{array}$ & $\begin{array}{lr}\begin{array}{l}\text { Coordination } \\
\text { civil with } \\
\text { organizations/private } \\
\text { sector }\end{array} & \end{array}$ \\
\hline \multirow[t]{3}{*}{$\begin{array}{l}\text { District/ } \\
\text { Municipalit } \\
\text { y }\end{array}$} & $\begin{array}{l}\text { Coordination } \\
\text { between different } \\
\text { units of district } \\
\text { government }\end{array}$ & $\begin{array}{lr}\begin{array}{l}\text { Coordination } \\
\text { civil with } \\
\text { organizations/ }\end{array} \\
\text { private sector }\end{array}$ \\
\hline & \multicolumn{2}{|c|}{ Vertical Coordination } \\
\hline & Internal & External \\
\hline Provincial & $\begin{array}{l}\text { Coordination } \\
\text { between province } \\
\text { and ministries } \\
\text { related on waste } \\
\text { management }\end{array}$ & $\begin{array}{l}\text { Coordination (a) } \\
\text { upwards to the } \\
\text { national organization } \\
\text { and (b) downward to } \\
\text { district/municipal } \\
\text { level. }\end{array}$ \\
\hline $\begin{array}{l}\text { District/ } \\
\text { Municipalit } \\
\text { y }\end{array}$ & $\begin{array}{l}\text { Coordination } \\
\text { between districts } \\
\text { and provincial } \\
\text { government } \\
\text { related on waste } \\
\text { management } \\
\text { Coordination (a) } \\
\text { upwards to the } \\
\text { provincial } \\
\text { organization and } \\
\text { (b) downward to } \\
\text { sub-district level. }\end{array}$ & $\begin{array}{l}\text { Coordination (a) } \\
\text { upwards to provincial } \\
\text { organization and (b) } \\
\text { downward to sub- } \\
\text { district level. }\end{array}$ \\
\hline
\end{tabular}

Source: Research Data, 2016

The research found the coordination system on waste management conducted by the provincial government is far from ideal where there is no a certain framework as well as the clear plan of actions on waste management coordination. Provincial government arranged some meetings among provincial government, district and municipal government discussing on integrated waste management in the area. The main agenda of the meeting are the possibility of establishing integrated sanitary landfill in one of the districts and land provision for sanitary landfill side. The meeting however is used to deadlock by some reasons for instance the policy maker on district or municipal 
level didn't attend the meeting and the meeting used to end up without solutions.

In carrying out the service on waste management, district or municipality establish units of government responsible for administrating, implementing, monitoring and evaluation waste management. Since the district or municipal government having genuine autonomous right on waste management the provincial government does not directly carry out waste management service to the field yet merely implementing limited actions can be done in line with the regulation on waste management. This situation is in fact very contradictive regarding to the position of the province as the coordinator of delivering public services in the integrated area of Mebidangro. The context of coordinator is surely presumed to only coordinate actions, monitoring the process, and evaluate the achievements in order to achieve one main goal. However, the unavailability of authorities to directly implement waste management on the ground seems to be ineffective.

Up to the year of 2016, the provincial government of North Sumatra has only ratified Governor Regulation No 5/2016 on Establishing of Mebidangro Operating Body as part of the provincial roles on coordinating waste management. The regulation is the recommendation of the Presidential Regulation No. 62/2011 as well. Since the regulation has been issued last four years, it is then assumed the provincial government is too late to formulate regulation. The operating body of Mebidangro as stipulated in the governor regulation will consist of representatives from District and Municipal Government in Mebidangro, Civil Society Institution and business. The organizational structure of the Mebidangro Operating Body consists of the Board of Trustee and Daily Management. Board of Trustee consists of (i) governor as a chairman, (ii) vicegovernor as a vice chairman, (ii) province secretary as secretary and (iv) major of Medan and Binjai and regent of Deli Serdang and Karo respectively as a member. The daily management consists of the chairman, secretary, desk of cooperation and desk of business.

Since the governor regulation on establishing operating body of Mebidangro has just issued and there will be a long way, step and plan of actions to be conducted in the sector of waste management. In addition, the regulation itself is not merely focused on waste management yet must be focussed on all sectors of services as stipulated in the presidential regulation. The regulation is furthermore, at least, regarded as a milestone to ensure the waste management system will be conducted comprehensively, integrated and sustainable. It is assumed since the operational director is not only coming from government official yet possible to be elected from professional. In addition, since the board of trustee consists of majors and regents in the area, the representation of each local government in the level of district or municipality will be adopted as well.

Looking back on waste management in the district or municipal level, the situation is more less the same to the progress of waste management services implemented by the provincial government. Among four districts or municipalities in the area of Mebidangro, the only local government having regulated waste management on their local regulation is the municipal of Medan notably by issuing the Local Regulation No.6/2015 on waste management. It is then justified the waste management and services related on waste management still doesn't become the local priority for the time being. An informant from the District of Deli Serdang and the District of Karo for instance saying the district governments priorities are improving artery roads and clean water within the districts rather than implementing services on waste management.

\section{Restructuring Governmental Offices in the Context of Waste Management}

Public administration is defined as governmental administration and operates in the particular sphere of government (Lamidi, 2015). One of public administration disciplines focuses in practice is how governmental organization or units adjust its offices, structures, line-up and functions in order to deliver public services in accordance to public needs. The local government institutions or units have come to play an important role for instance in accelerating the pace of development (Sikander, 2015). To reach the important role of the government units the size and the characteristic of governmental units is furthermore pivotal to ensure the public services can be effectively delivered and reach effectiveness. Efficiency refers to "getting the most output from the least amount of input" and effectiveness is often described as "doing the right 
thing, that is, engaging in activities that will help government agency reach its goals (Starling, 2005).

In the context of waste management system conducted by districts and municipalities in Mebidangro, the establishment of local offices, structure and organizational line-up are different from each other. The municipality of Medan has more local offices having direct functions and roles on waste management comparing to three other districts or municipality in the integrated are of Mebidangro. The municipal of Binjai has more local offices than those of within the district of Deli Serdang and Karo. Most local offices within districts or municipalities government are categorized as echelon 2 which implies the organization structure and public officers within are bigger then sub-office which is echelon 3 . The annual budget delivered to the office is automatically bigger than those of suboffices or echelon 3. According to this study, the district and municipal governments implement different pattern on establishing local government units which are adjusted to previous government regulation notably by the Government Regulation No. $41 / 2007$.

In the context of the district of Deli Serdang, it is found there is no office of local cleanness within district government structure. The government unit having responsibilities on handling waste management is focussed to be carried out by the subdistrict government. Informant from the government side tells the waste management will be more effective to be conducted by sub-district government since they are directly able to monitor, evaluate and control the piles of waste in their respective area. The ideal policy and local strategy of the district do not match with the real fact on the ground. Piles of waste in the district is worse rather those of within Karo and Binjai.

The establishment of local offices having functions and responsibility on waste management must be adjusted to the population of the district or municipal, number of sub-district and village, annual budget as well as the area coverage. The number of public officers working in the related-waste management office must be at least based on the mentioned indicators. The law No. 23/2014 as the last revision of local governance law puts the addendum on local offices which are furthermore regulated through the Government Regulation No.18/2016 on Local Offices. In the Article 2 of the Government Regulation No.18/2016 stipulates the establishing of the local offices, number of officer as well as echelons within unit of local government must be based on sector of services which are the authority of local government, governance affairs intensity and potentials, efficiency, effectiveness, distributed job divisions, span of control, certain work structure and flexibility. The impact of the regulation is the restructuring of local government offices based on those above mentioned principles. There must be some adjustments on existing local offices at the provincial, district or municipal level. The impact of the regulation will also bring changes and adjustments on local government institutions in charging for waste management.

Table 3. Comparison of Population, Annual Budget, Officials and Area Coverage in Mebidangro Area

\begin{tabular}{|l|r|r|r|c|}
\hline District & $\begin{array}{c}\text { Populatio } \\
\mathrm{n}\end{array}$ & $\begin{array}{c}\text { Annual } \\
\text { Budget } \\
\text { (Million } \\
\text { IDR) }\end{array}$ & $\begin{array}{c}\text { Area } \\
\left(\mathrm{Km}^{2}\right)\end{array}$ & Offi-cials)* \\
\hline Medan & $2,191,140$ & 4,042 & 265 & 945 \\
\hline Binjai & 252,652 & 780 & 90 & 213 \\
\hline $\begin{array}{l}\text { Deli } \\
\text { Serdang }\end{array}$ & $1,984,598$ & 2,450 & 2,497 & 343 \\
\hline Karo & 382,622 & 992 & 2,127 & 115 \\
\hline
\end{tabular}

Source: Central Bureau of Startistic, $2015^{*}$ Counted The Local Officials on Waste-Related Offices

The Table 3 above shows the ratio of the number of officials to the number of population which are the residents on waste management issues in Medan, Binjai, Deli Serdang and Karo are respectively: (0.000431), (0.000843), $(0,000173)$ and $(0,000301)$. The figures mean one public official from related waste management unit of the municipality of Medan must in charge to as many as 2,319 residents in the area while as many as 1,186 residents in Binjai; 5,788 residents in Deli Serdang and 3,327 residents in Karo. The interpretation of this data also implies the municipal of Binjai is the best ratio on available official to serve on waste management while the district of Deli Serdang ratio is the worst. This interpretation is just based on the statistic data meaning there are some other indicators used by local government to adjust the number of public officials on handling waste management. 


\section{CONCLUSION}

The research found the coordination on waste management which the provincial government on the driver seat doesn't properly work in line with The Presidential regulations. The district or municipality governments in the region mostly do not have a clear and certain framework on waste management. The research also found the establishment of the governmental units on waste management at district/municipal level is not based on the newest regulation yet and it contibutes the improper waste management service.

\section{REFERENCES}

Adogu, P.O.U et.al. (2015).Assessment of Waste Management Practices among Residents of Owerri Municipal Imo State Nigeria, Journal of Environmental Protection, Imo State Nigeria. pp. 447.

Babatunde, Osabiya J. (2003). Introduction To Public Administration, National Open University of Nigeria, School of Management Sciences http://www.nou.edu.ng/uploads/NOUN OCL/ pdf/SMS/PAD202\%20INTRODUCTION\%20T0 \%20PUBLIC\%20ADMINISTRATION.pdf accessed 12 August 2016.

Central Bureau of Statistic/BPS I. (2015). Binjai in Figures of 2015, Binjai Central Bureau of Statistic (BPS), Binjai, Indonesia

Central Bureau of Statistic/ BPS II. (2015). Deli Serdang in Figures of 2015, Deli Serdang Central Bureau of Statistic, Lubuk Pakam, Indonesia.

Central Bureau of Statistic/BPS III. (2015). Karo in Figures of 2015, Karo Central Bureau of Statistic (BPS), Kabanjahe, Indonesia.

Central Bureau of Statistic/BPS IV. (2015). Medan in Figures of 2015", Karo Central Bureau of Statistic (BPS), Medan, Indonesia.

Christensen, Tom. (2015). The Challenges of Coordination in National Security Management-the Case of the Terrorist Attack in Norway, Journal, International Review of Administrative Sciences 2015, Vol. 81(2) pp. 352-372.

Gortner, Harold et al. (1997). Public Organization Theory: A Public Perspective, Second Edition, Harcourt Brace \& Company, Florida, USA.

Hasibuan, Malayu S.P. (2011). Basic Management,
Undestanding and Problems, Jakarta, Bumi Aksara (in Indonesian Language)

Isufaj, Mentor. (2014). Decentralization and the Increased autonomy in Local Governments, 2nd World Conference On Business, Economics And Management, Elsevier Ltd, pp. 459-463.

Ind II-Aus Aid. (2011). Scoping Study Solid Waste Management Indonesia, Technical Report, July 2011,

http://indii.co.id/images/import file/2012062 61043390.Scoping\%20Study\%20for\%20Solid \%20Waste\%20Management $\% 20 \mathrm{in} \% 20$ Indone sia.pdf (accessed on 20 August 2016).

Joyce, Paul. (2000). Strategy in the public sector: A guide to Effective Change Management, John Wiley \& Son. Ltd, Singapore.

Kral, Jaroslav. (2009). Communications And Coordination In Construction Projects, Journal Construction Management and Economics" (January 2009) 27, 25-39. http://dx.doi.org/10.1080/014461908025589 $\underline{23}$ accessed on 21 August 2016

Nasution, Indra Kesuma. (2014). Democracy and Decentralization: Explaining the Ethnic Political Participation of Direct Election in Medan 2010, Journal, The 4th International Conference on Sustainable Future for Human Security, Elsevier Ltd, pp. 497-505.

Nugraha, Pepih. (2016). Leuwigajah, Kami Takkan Lupa...,13 November 2016, Kompas Online, http://sains.kompas.com/read/2011/02/21/2 0382467/leuwigajah.kami.takkan.lupa. accessed on 5 November 2016.

Osifo, Charles. (2012). Organization And Coordination: An Intra-And Inter Performance Perspective, Working Paper, The University of Vaasa, Vaasa, Finland, March 2012.

Seadon. (2010). Sustainable waste management systems, Journal of Cleaner Production pp. 1639-1651.

Sikander, Tasneem. (2015). A Theoretical Framework of Local Government, Journal, International Journal of Humanities and Social Science, Vol. 5, No. 6(1); June 2015 Center for Promoting Ideas, USA

Starling, Grover. (2005). Managing the Public Sector, Seventh Edition, Thomson Wadsworth, Belmont, USA.

Wojtarowicz, Natalie and Herold, David M. (2014). Coordination Practices in Federal Government: The Case of Integration Policy in Austria, 
Journal of Economic and Social Policy: Vol. 16:

Iss. 2, Article 10. Available at:

http://epubs.scu.edu.au/jesp/vol16/iss2/10

accessed on 23 August 2016. 